\title{
Green Tea (Camellia sinensis) Extract Induces p53-Mediated Cytotoxicity and Inhibits Migration of Breast Cancer Cells
}

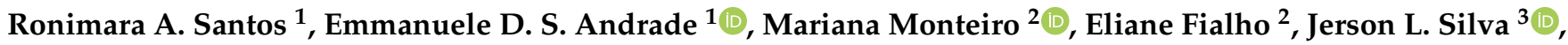 \\ Julio B. Daleprane ${ }^{1}$ (I) and Danielly C. Ferraz da Costa ${ }^{1, *}$ \\ 1 Laboratory for Studies of Interactions between Nutrition and Genetics, Department of Basic and \\ Experimental Nutrition, Rio de Janeiro State University, Rio de Janeiro 20550-013, Brazil; \\ ronimaras@gmail.com (R.A.S.); manu.dutra.pbi@gmail.com (E.D.S.A.); juliobd@gmail.com (J.B.D.) \\ 2 Laboratory of Functional Foods, Institute of Nutrition Josué de Castro, Federal University of Rio de Janeiro, \\ Rio de Janeiro 21941-902, Brazil; mariana@nutricao.ufrj.br (M.M.); elianefialho@yahoo.com.br (E.F.) \\ 3 National Institute of Science and Technology for Structural Biology and Bioimaging, Federal University of Rio \\ de Janeiro, Rio de Janeiro 21941-902, Brazil; jerson@bioqmed.ufrj.br \\ * Correspondence: daniellyferraz@ymail.com
}

check for updates

Citation: Santos, R.A.; Andrade, E.D.S.; Monteiro, M.; Fialho, E.; Silva, J.L.; Daleprane, J.B.; Ferraz da Costa, D.C. Green Tea (Camellia sinensis) Extract Induces p53-Mediated Cytotoxicity and Inhibits Migration of Breast Cancer Cells. Foods 2021, 10, 3154. https://doi.org/10.3390/ foods10123154

Academic Editor: Antonello Santini

Received: 29 October 2021

Accepted: 14 December 2021

Published: 20 December 202

Publisher's Note: MDPI stays neutral with regard to jurisdictional claims in published maps and institutional affiliations.

Copyright: (c) 2021 by the authors. Licensee MDPI, Basel, Switzerland. This article is an open access article distributed under the terms and conditions of the Creative Commons Attribution (CC BY) license (https:// creativecommons.org/licenses/by/ $4.0 /$ )

\begin{abstract}
Green tea (GT) has been shown to play an important role in cancer chemoprevention However, the related molecular mechanisms need to be further explored, especially regarding the use of GT extract (GTE) from the food matrix. For this study, epigallocatechin gallate (EGCG) and epigallocatechin (EGC) were identified in GTE, representing 42 and $40 \%$ of the total polyphenols, respectively. MDA-MB-231 (p53-p.R280K mutant) and MCF-7 (wild-type p53) breast tumor cells and MCF-10A non-tumoral cells were exposed to GTE for 24-48 h and cell viability was assessed in the presence of $\mathrm{p} 53$ inhibitor pifithrin- $\alpha$. GTE selectively targeted breast tumor cells without cytotoxic effect on non-tumoral cells and p53 inhibition led to an increase in viable cells, especially in MCF-7, suggesting the involvement of p53 in GTE-induced cytotoxicity. GTE was also effective in reducing MCF-7 and MDA-MD-231 cell migration by 30 and 50\%, respectively. An increment in p53 and p21 expression stimulated by GTE was observed in MCF-7, and the opposite phenomenon was found in MDA-MB-231 cells, with a redistribution of mutant-p53 from the nucleus and no differences in p21 levels. All these findings provide insights into the action of GTE and support its anticarcinogenic potential on breast tumor cells.
\end{abstract}

Keywords: polyphenols; catechins; antioxidant capacity; cell viability; cell cycle

\section{Introduction}

Camellia sinensis leaves provide one of the most popular manufactured drinks in the world, thus representing the second most consumed beverage after water. China is the largest tea producing country with an output of 1.9 million tons, accounting for more than 38 percent of the world total. Tea is widely consumed all over the countries, especially in China and India, and usually categorized into three types-green, black, and oolong-due to leaf fermentation degree and processing [1-3]. Green tea (GT) is produced by drying and steaming tea leaves to prevent fermentation and is considered a great source of natural polyphenols that accounts for 30 to $42 \%$ of the composition of the dry extract of the plant, depending on cultivation conditions. The major groups of these polyphenols belonging to the group of flavonoids are catechins (flavan-3-ol) and include epicatechin (EC), epicatechin gallate (ECG), epigallocatechin (EGC) and epigallocatechin gallate (EGCG). The presence of numerous hydroxyl groups in these molecules gives them strong antioxidant properties [4,5].

Available scientific studies indicate a significant impact of the diet and its natural phytochemicals on the prevalence of chronic non-communicable diseases [6]. Antiinflammatory and antioxidant as well as chemopreventive activity are considered the most 
important hallmarks of the GT catechins, encouraging the inclusion of tea in the daily $\operatorname{diet}[7]$.

Evidence from case-control studies suggests that GT consumption may promote reduced incidence of breast cancer [8,9]. A recent umbrella review and meta-analysis of observational studies regarding tea consumption and risk of cancer showed that high consumption compared with low GT consumption significantly lowered the risk of breast cancer [10]. Further investigation is needed to provide evidence of the GT role in the overall risk of cancer [11].

Overall, the use of GT in cancer research is a promising strategy considering that recent studies expected 19.3 million new cases of cancer and 10 million deaths from cancer in 2020, including breast cancer. Female breast cancer was pointed as the leading cause of global cancer incidence in 2020, with an estimated 2.3 million new cases, representing $11.7 \%$ of all cancer cases [12]. Metastatic breast cancer is responsible for more than $90 \%$ of cancer-related deaths [13]. The etiology of breast cancer is multifactorial and in recent years, preclinical and clinical research provided growing evidence with respect to the protective effects of bioactive plant derived compounds on cancer-related biological pathways [14]. Phytochemicals may affect the carcinogenesis process from initiation to progression by improving detoxification, enhancing innate immune surveillance, promoting DNA repair, and inhibiting cell proliferation $[15,16]$. The main mechanisms of action of catechins include the modulation of cell-cycle related proteins, induction of apoptosis, modulation of transcription factors and important intracellular enzymes involved in migration, invasion, metastasis, inhibition of inflammatory factors, and modulation of membrane receptors [17-19].

Molecular mechanisms involved in the physiopathology of cancer are still limited, but a promising field in oncology research is tumor-suppressor proteins such as the p53 family. p53 is involved with a range of antitumor mechanisms, including induction of cell cycle arrest, senescence, and apoptosis, and reducing proliferative signaling [20]. Interestingly, the p53 family is considered a chemotherapeutic target of polyphenols, including GT catechins [21,22].

Most studies regarding the effects of polyphenols are commonly conducted by the administration of supplements or isolated compounds, and include limitations such as side effects related to high doses and poor bioavailability of catechins [23]. The presence of diverse bioactive compounds in GT matrix may increase the bioaccessibility, bioavailability, and efficacy of catechins, assuring an advantage over isolated compounds. Moreover, GT beverages are better tolerated when compared to capsules or bolus, due to liver toxicity promoted by free catechins [24]. It is important to notice that, although with very low frequency, toxicological studies show a hepatocellular pattern of liver injury with isolated EGCG intake amounts ( 140-1000 mg/day). One of the recognized factors that can contribute to the hepatotoxic effects is the bolus dose provided by certain dosage forms such as capsules and tablets. These data encourage the inclusion of tea in the daily diet, instead of supplementation [25].

Regarding the recent evidence about GT effects on breast cancer [26], we hypothesized that a green tea extract (GTE) obtained from the food matrix could promote p53-mediated anticancer effects on human breast cancer cells. We found that GTE selectively targeted MDA-MB-231 and MCF-7 cells, thus reducing cell viability and migration without cytotoxic effect on non-tumoral cells, which suggests a high potential for application in carcinogenesis. Our data also show the involvement of the tumor suppressor p53 and p21 protein in GTE-mediated cytotoxicity.

\section{Materials and Methods}

\subsection{Chemicals and Reagents}

All reagents were analytical grade and water was obtained with a Milli-Q system from Millipore (Bedford, MA, USA). Pifithrin- $\alpha$ and Alamar Blue ${ }^{\circledR}$ were purchased from Invitrogen (Carlsbad, CA, USA). Dimethyl sulfoxide (DMSO), trypsin, antibiotics (peni- 
cillin, streptomycin), fetal bovine serum, Mammary Epithelial Growth Supplement (MEGS), Dulbecco's Modified Eagle's Medium (DMEM) media were purchased from Thermo-Fisher Scientific (Saint Louis, MO, USA). Mitomycin-C, iron chloride hexahydrate and 2,4,6-tris(2pyridyl)-S-triazine (TPTZ) were purchased from Sigma-Aldrich Chemical Co (Saint Louis, MO, USA). Anti-p53 (DO-1) and anti-GAPDH (0411) antibodies were purchase from Santa Cruz Biotechnology (Santa Cruz, CA, USA). Anti-p21 (12D1) antibody was purchased from Cell Signaling Technology (Danvers, MA, USA). Anti- $\beta$-actin (A1978) antibody was purchased from Sigma-Aldrich Chemical Co (Saint Louis, MO, USA). Catechin standards were purchased from Indofine Chemical Co. (Hillsborough, NJ, USA).

\subsection{Green Tea Extract Polyphenols Quantification and Antioxidant Capacity}

To investigate the effect of infusion time and temperature on polyphenols content and antioxidant capacity, a commercial brand of oven-roasted green tea, grown in two mountainous regions of the Brazilian coast, where the climate is similar to Japan's and whose processing employs Japanese technology, was acquired in a local market in Rio de Janeiro, Brazil. Aqueous infusions were prepared in a proportion of $1 \mathrm{~g}: 40 \mathrm{~mL}$ and submitted at $70,75,80,85,90,95$, and $100{ }^{\circ} \mathrm{C}$ during 5,10 , and $15 \mathrm{~min}$. Total polyphenols content was determined according to the Folin-Ciocalteu assay [27] and results were expressed as mg of gallic acid equivalents (GAE) per liter (mg EAG/L). Antioxidant capacity was determined by the Ferric Reducing Ability Power (FRAP) assay as described previously [28,29]. (FRAP reagent was prepared by mixing $2 \mathrm{~mL}$ of $10 \mathrm{mM}$ TPTZ solution in $6 \mathrm{M} \mathrm{HCl}$ with $2 \mathrm{~mL}$ of $20 \mathrm{mM}$ ferric chloride solution and $20 \mathrm{~mL}$ of $300 \mathrm{mM}$ acetate buffer (pH 3.6) and warmed to $37^{\circ} \mathrm{C}$ prior to analysis. In a microplate, $20 \mu \mathrm{L}$ of samples and $180 \mu \mathrm{L}$ of the FRAP reagent were added, followed by reading at $595 \mathrm{~nm}$ (Biochrom ${ }^{\circledR}$ Asys UVM340; Holliston, MA, USA) after 4 min of incubation. Results were quantified based on a standard curve of ferrous sulfate and were expressed as $\mathrm{mmol} \mathrm{Fe}^{2+}$ per liter of extract $\left(\mathrm{mmol} \mathrm{Fe}^{2+} / \mathrm{L}\right)$. Each extract was analyzed in triplicate.

\subsection{Characterization of Green Tea Extract Polyphenols by HPLC}

After determination of the best GTE extraction condition, a fresh GTE infusion $\left(80^{\circ} \mathrm{C} / 5 \mathrm{~min}\right.$ ) was prepared and freeze-dried (LD3000 Freeze Drier; Terroni, SP, Brazil) in order to be applied in the cell culture. GTE was stored at $-20^{\circ} \mathrm{C}$ protected from light. The contents of catechin in GTE were determined by High-Performance Liquid Chromatography (HPLC) analysis. The HPLC system (Shimadzu ${ }^{\circledR}$, Kyoto, Japan) included two LC-20AD pumps, automatic injector SIL-20AHT, diode array detector SPD-M20A, system controller CBM-20A, and degasser DGU-20A5. Chromatographic separation of catechins was achieved using a reverse-phase column C18 $\left(5 \mu \mathrm{m}, 250 \mathrm{~mm} \times 4.6 \mathrm{~mm}\right.$, Kromasil ${ }^{\circledR}$, Darmstadt, Germany). The mobile phase consisted of a gradient of $0.3 \%$ formic acid and $1 \%$ acetonitrile in water (eluent $\mathrm{A}$ ) and $1 \%$ acetonitrile in methanol (eluent $\mathrm{B}$ ), at a flow rate of $1.0 \mathrm{~mL} / \mathrm{min}$. Prior to injection, the column was equilibrated with $18.2 \%$ B. After sample injection, the solvent composition changed to $20.2 \% \mathrm{~B}$ in $1 \mathrm{~min}, 43.4 \% \mathrm{~B}$ in $18 \mathrm{~min}$, and $85.9 \%$ B in $23 \mathrm{~min}$, and kept constant until $30 \mathrm{~min}$ between injections, $10 \mathrm{~min}$ intervals were used to re-equilibrate the column with $18.2 \%$ B. The eluent was monitored by DAD at 210 and $280 \mathrm{~nm}$. The injection volume was $10 \mu \mathrm{L}$. Identification of catechin (C), epicatechin (EC), epigallocatechin (EGC), epigallocatechin gallate (EGCG) and epicatechin gallate (ECG) was performed by comparison with retention time and absorption spectrum of the respective standard. Quantification was performed by external calibration. Data were acquired by LabSolutions software (Shimadzu Corporation ${ }^{\circledR}$, Sydney, Australia, version $5.82,2015)$.

\subsection{Cell Culture}

The human breast epithelial carcinoma cell lines MDA-MB-231 (mutated p53-p.R280K) and MCF-7 (wild-type p53) were obtained from the American Type Culture Collection (ATCC; Manassas, VA, USA). Cells were cultured in DMEM containing $4.5 \mathrm{~g} / \mathrm{L}$ glucose 
supplemented with $10 \%$ fetal bovine serum and $1 \%$ of penicillin/streptomycin. Cells were maintained at $37{ }^{\circ} \mathrm{C}$ in a humidified atmosphere containing $5 \% \mathrm{CO}_{2}$. The non-tumoral MCF-10A cells, obtained from the American Type Culture Collection (ATCC; Manassas, VA, USA) were cultured at the same conditions, plus adding MEGS supplementation.

\subsection{Cell Treatment}

Breast cancer cells were subcultured into 24- or 96-well plates and, upon adherence, supplementation of SFB culture medium was reduced to $2 \%$ for cell cycle synchronization for at least $12 \mathrm{~h}$ until reaching $60 \%$ confluency. In order to set the $\mathrm{IC}_{50}$ value, cells were exposed for 24 or $48 \mathrm{~h}$ to the following concentrations of GTE: 31.2, 62.5, 125, 250, 500, 750, and $1000 \mu \mathrm{g} / \mathrm{mL}$. To be applied in culture, the GTE was diluted in complete DMEM medium and filtered in $0.22 \mu \mathrm{m}$ filter. The use of this approach in breast cells is justified by previous studies which detected the presence of phenolic compounds derived from plant extract sources, including intact catechins, in different non-intestinal tissues [30].

\subsection{Cell Viability}

After treatment, cells were exposed to $10 \%$ Alamar's reagent diluted in culture medium for $3 \mathrm{~h}$ and held at $37^{\circ} \mathrm{C}$ in a humidified atmosphere containing $5 \% \mathrm{CO}_{2}$. The plate was read in a spectrophotometer at 570 and $600 \mathrm{~nm}$, and the data were expressed as \% of viability in comparison to the control. A trypan blue exclusion test was also performed to access the effect of GTE on cells viability. Cells were treated as described before, washed with PBS, and resuspended with $100 \mu \mathrm{L}$ of trypsin in $500 \mu \mathrm{L}$ of $2 \%$ DMEM. An aliquot was stained with Trypan Blue dye (1:1) and the viable cells were immediately counted in Neubauer's Chamber using an optical microscope. Results were expressed in \% of viable cells. The same experiment was performed using a specific p53 inhibitor (pifithrin- $\alpha$ ).

\subsection{Selectivity Index}

The degree of selectivity of GTE was expressed as previously reported [31], in accord to Equation (1).

$$
\text { Selectivity index }(\mathrm{SI})=\frac{\mathrm{IC50} \text { tumor cells }}{\mathrm{IC50} \mathrm{MCF}-10 \mathrm{~A}}
$$

\subsection{Wound-Healing Assay}

To determine the effect of GTE on cell migration capability, wound-healing assay was performed as previously described [32]. Cells were cultured as described before until reaching 50-60\% confluence. Cells monolayers were then washed with PBS and scratched with a sterile plastic $\mathrm{p} 10$ pipette tip. Wounds were made in triplicates. The peeled off cells were removed with two PBS washes and a fresh media containing different concentrations of GTE and a proliferation inhibitor, mitomycin-C $(0.5 \mu \mathrm{g} / \mathrm{mL})$, was added. Cells were treated with $48 \mathrm{~h}$ and images at zero and final time-points were acquired under a brightfield microscope, using a $10 \times$ objective. Wound width was measured using the ImageJ software version 1.43p (NIH, Bethesda, NY, USA).

\subsection{Western Blotting}

GTE-treated cells for $24 \mathrm{~h}$ were lysed and the protein concentration was determined using a Bio-Rad Protein assay (Bio-Rad Laboratories, Richmond, CA, USA). Proteins (50-100 $\mu \mathrm{g}$ ) were resolved on 10\% SDS-polyacrylamide gel and transferred into PVDF membrane. The membranes were incubated with blocking buffer (50 mM Tris, $200 \mathrm{mM}$ $\mathrm{NaC} 1,0.2 \%$ Tween 20 , and 5\% BSA) for $2 \mathrm{~h}$ followed by the incubation with anti-p53, antip21, anti-GAPDH, and anti- $\beta$-actin antibodies (1:1000) overnight at $4{ }^{\circ} \mathrm{C}$. The membranes were then washed with TBS-T buffer and incubated with secondary antibody conjugated with peroxidase for $1 \mathrm{~h}$ at room temperature. A Clarity Western ECL Substrate kit (Bio-Rad Laboratories, Richmond, CA, USA) was used for chemodetection. Levels of GAPDH and $\beta$-actin were used as an internal control to verify the loading of proteins in the gel. The 
densitometric quantification of bands was performed using Image Lab software (Bio-Rad Laboratories, Richmond, CA, USA).

\subsection{Immunocytochemistry}

Cells were grown at $70-80 \%$ confluence in 24 -well plates on $13 \mathrm{~mm}$ glass coverslips and after cell cycle synchronization were treated with different concentrations of GTE for $24 \mathrm{~h}$. Subsequently, cells were washed with PBS and fixed with a methanol:acetone solution (1:1) for $30 \mathrm{~min}$. After further washing with PBS, cells were labeled with the anti-p53 primary antibody (1:200-2 h) followed by secondary Alexa Fluor 488 anti-mouse antibody (1:1000-1 h) and Hoechst 33,342 to nucleus identification in a dark chamber. Glass coverslips were mounted in a drop of glycerol for microscopical analysis. To obtain the images, a confocal laser scanning microscope was used (Leica TCS SPE, Wetzlar, Germany).

\subsection{Statistical Analysis}

Data were expressed as averages of at least three independent measurements \pm standard deviation (SD). We confirmed the data for normal distribution and homoscedasticity of the variance using Shapiro-Wilk test, and then the groups were compared using one-way analysis of variance (ANOVA). Differences between pifithrin- $\alpha$ treated groups and control groups were evaluated using a Student's $t$-test. Differences between GTE treated groups and control groups were evaluated using a Student's $t$-test for p53 and p21 expression. In all cases, $p$ value $<0.05$ was accepted as statistically significant using GraphPad Prism Software v6.01 (San Diego, CA, USA).

\section{Results}

\subsection{Time and Temperature Did Not Influence Polyphenol Content and Antioxidant Capacity of Green Tea Extract}

To determine the best infusion condition to obtain a catechin-rich GTE, antioxidant capacity and polyphenol content of GT leaves were compared over a range of infusion times and temperature combinations. FRAP values ranged from 6.1 to $15.7 \mathrm{mmol} \mathrm{Fe} \mathrm{F}^{2+} / \mathrm{L}$ of infusion (Figure 1A) and total polyphenol content ranged between 1015 to $1823 \mathrm{mg}$ GAE/L of infusion (Figure 1B). Our data demonstrated no impact of the combination of time and temperature in the content of phenolic compounds and antioxidant capacity. From these results, the previous studies from literature and with the aim of mimic the routine conditions of preparation of green tea for consumption by the population, the binomial $80{ }^{\circ} \mathrm{C} / 5$ min was chosen to perform the next experiments.

HPLC analyses of catechin content were also performed and, as expected, EGCG was the major catechin in GTE, representing $42 \%$ of total catechins, followed by EGC (40\%), ECG $(12 \%)$ and C (6\%) (Table 1).

Table 1. Phenolic compounds contents in green tea extract.

\begin{tabular}{lc}
\hline Compound & Content $(\boldsymbol{\mu g} / \mathbf{m L})$ \\
\hline Catechin (C) & $5.06 \pm 0.15$ \\
Epicatechin gallate (ECG) & $9.44 \pm 0.01$ \\
Epigallocatechin (EGC) & $31.64 \pm 0.69$ \\
Epigallocatechin gallate (EGCG) & $32.83 \pm 0.15$ \\
$\sum$ catechins & $78.97 \pm 0.44$ \\
\hline
\end{tabular}



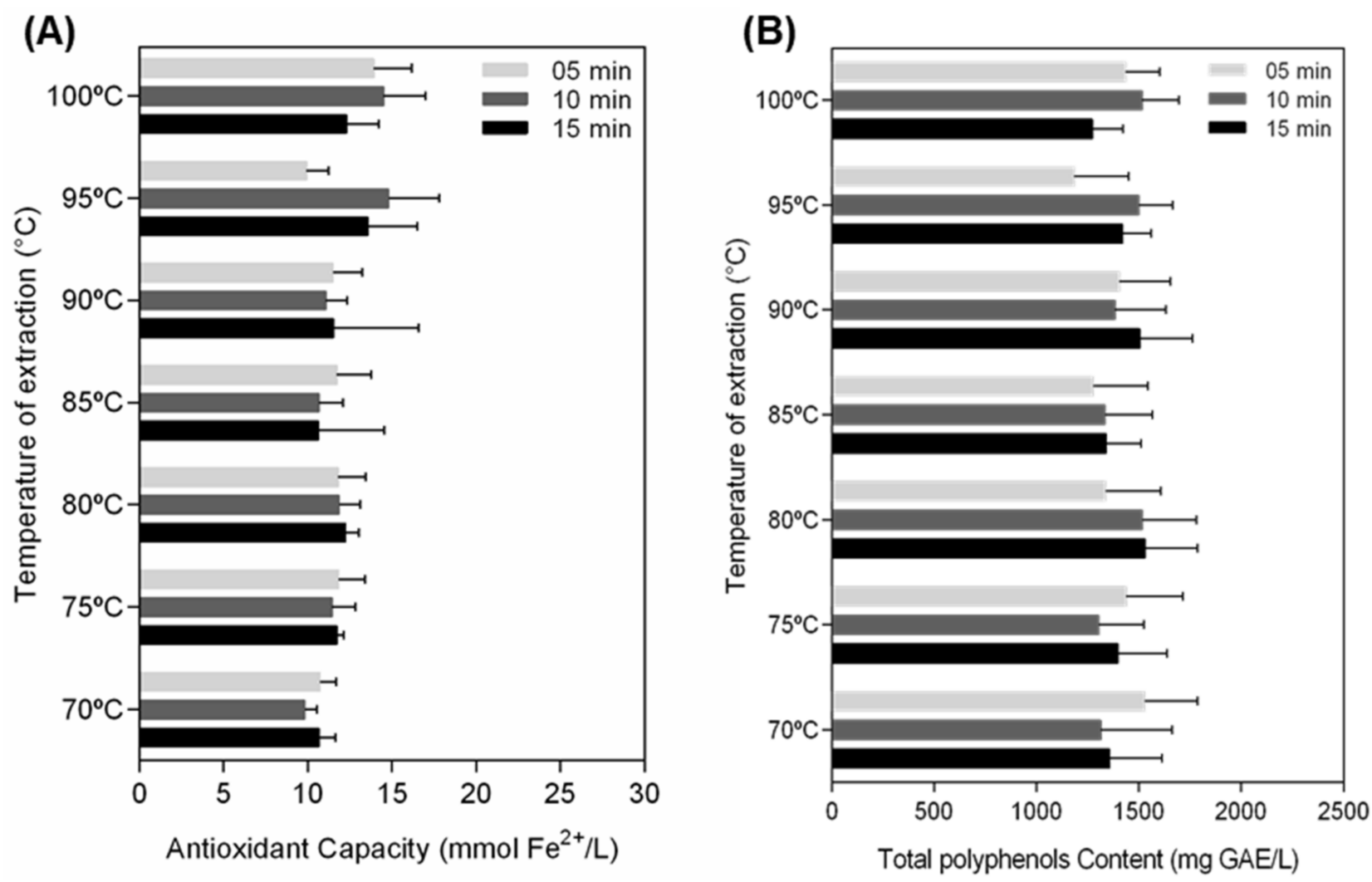

Figure 1. Effect of infusion time and temperature on antioxidant capacity and total polyphenols content of GTE. Antioxidant capacity (A) and total polyphenols content (B) were assessed by FRAP and Folin-Ciocalteau assays, respectively, after 5, 10, and $15 \mathrm{~min}$ of water extraction in different temperatures, as indicated. The results were expressed as averages of three independent measurements $\pm \mathrm{SD}$.

\subsection{Green Tea Extract Reduces MDA-MB-231 and MCF-7 Cells Viability}

To evaluate the anticancer potential of GTE, the breast cancer cells (MDA-MB-231 and MCF-7) and the non-tumoral human breast cell line (MCF-10A) were exposed to a range of GTE concentrations (31.2-1250 $\mathrm{gg} / \mathrm{mL}$ ) for 24 and $48 \mathrm{~h}$ and cell viability was accessed. As shown in Figure 2, Trypan Blue (Figure 2A,C) and Alamar Blue (Figure 2B,D) assays together demonstrated that GTE had a cytotoxic effect on both breast cancer cells. Treatment with GTE for $24 \mathrm{~h}$ displayed significant changes in cell viability, resulting in an $\mathrm{IC}_{50}$ value of 133 and $324 \mu \mathrm{g} / \mathrm{mL}$ for MDA-MB-231 and MCF-7 cells, respectively, considering Trypan Blue assay. No cytotoxic effect was demonstrated at the same concentrations on nontumoral cells MCF-10A (Figure 2E). GTE targets breast cancer cells selectively, and it was shown that it can be two times more specific for MDA-MB-231 cells than MCF-7 (Table 2).

Table 2. Comparison of cytotoxic activities of GTE.

\begin{tabular}{lcc}
\hline $\mathrm{IC}_{\mathbf{5 0}}(\boldsymbol{\mu \mathrm { g } / \mathrm { mL } )}$ & MCF-7 & MDA-MB-231 \\
\hline $24 \mathrm{~h}$ & 324 & 133 \\
Selectively index (SI) & 31.1 & 75.9 \\
\hline
\end{tabular}

\subsection{Green Tea Extract Inhibits Breast Cancer Cell Migration}

Since migration capability has been implicated in the control of tumor progression, we investigated if GTE could suppress the migration of MDA-MB-231 and MCF-7 cancer cells using the wound healing assay while cells were exposed to mitomycin $C$ to inhibit the proliferation. Our results showed that GTE reduced the migratory capability of both cells considering decreasing wound closure (Figure 3). MCF-7 is naturally less invasive since it formed tightly cohesive structures displaying robust cell-cell adhesions. For this reason, the 
MCF-7 monolayer was not completely closed in the negative control, even after incubation for $48 \mathrm{~h}$. However, a 30\% reduction in cell migration was observed at this condition when cells were exposed to $324 \mu \mathrm{g} / \mathrm{mL}$ of GTE (Figure 3A,B). A pronounced inhibition of migration was evidenced in the MDA-MB-231 cells, which form loosely cohesive grapelike or stellate structures that characterize its very aggressive tumor phenotype profile (Figure 3C,D). It was possible to observe the complete closure of the wound in the untreated cells already in $24 \mathrm{~h}$, a phenomenon that did not occur in the conditions that received the addition of $253 \mu \mathrm{g} / \mathrm{mL}$ of GTE.

(A)

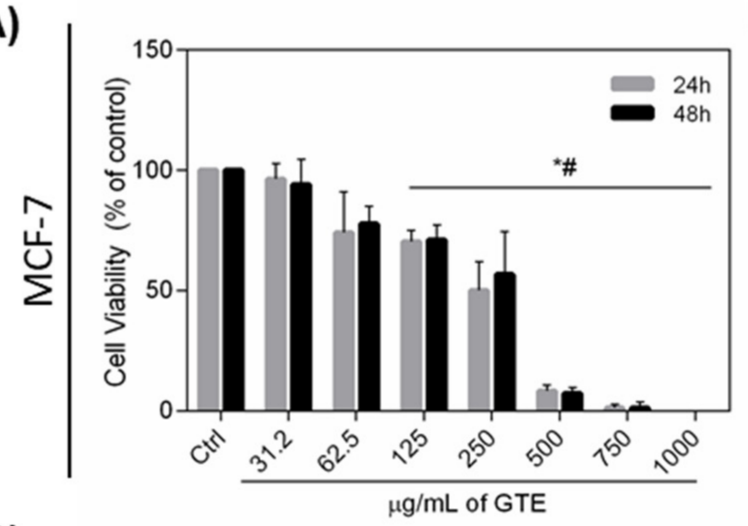

(C)

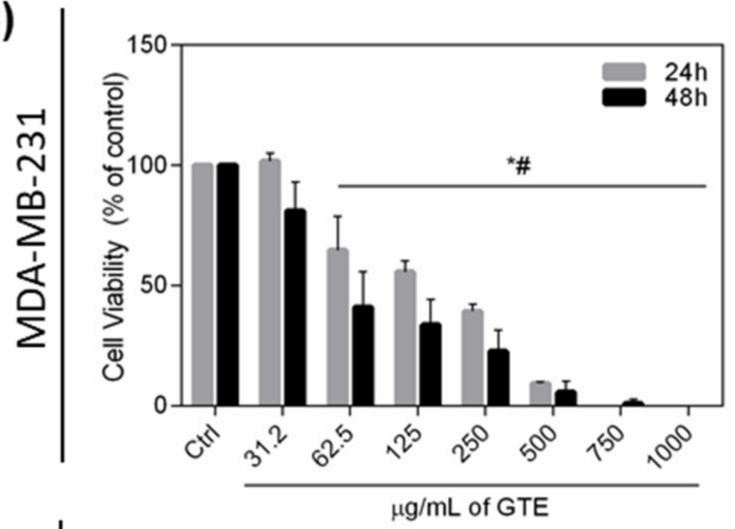

(E)

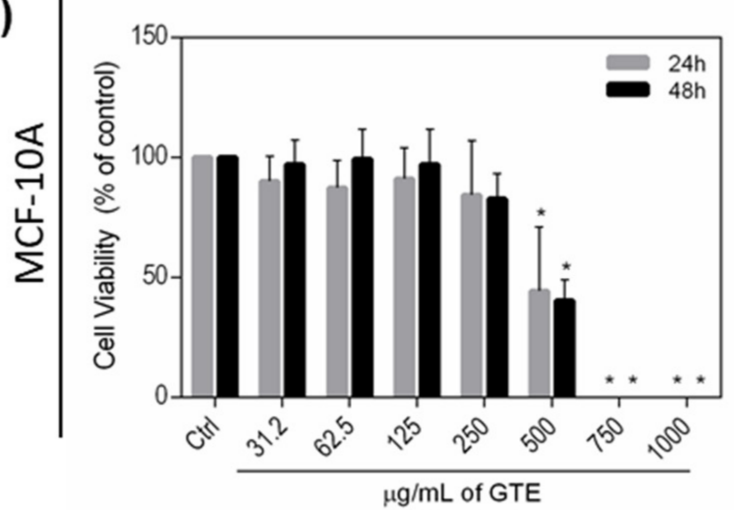

(B)

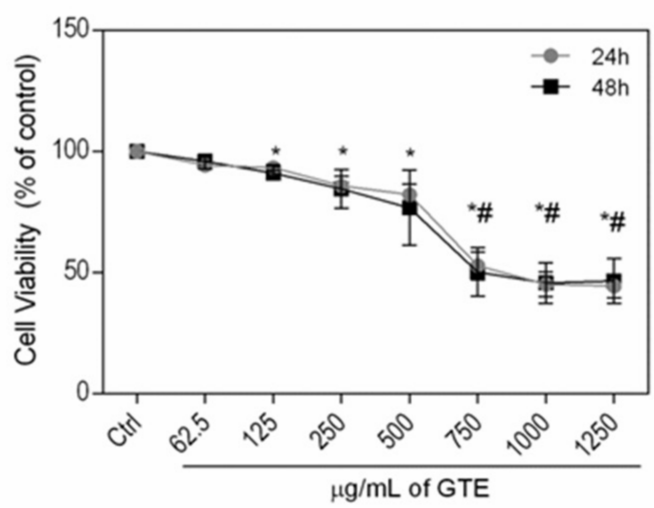

(D)

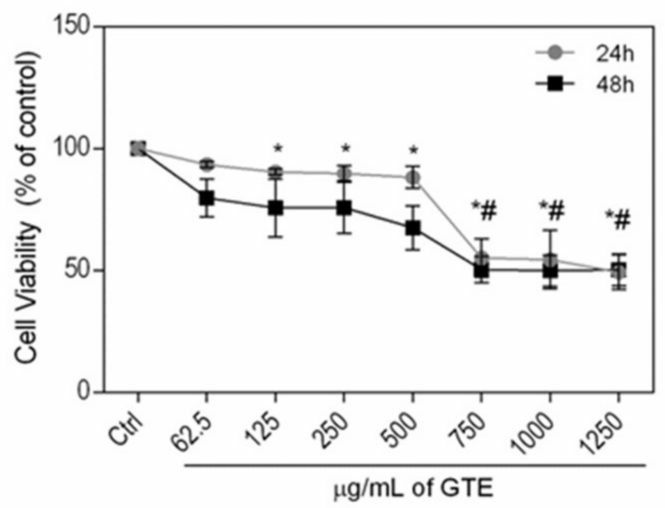

Figure 2. GTE treatment inhibits the proliferation potential and cell viability of human breast cancer MCF-7 and MDAMB-231 cells. Cells were treated with different GTE concentrations for $24-48 \mathrm{~h}$, as indicated. Cell viability was assessed by Alamar Blue (A,C) and Trypan Blue (B,D) assays. GTE was also tested on non-tumoral MCF-10A cells and viability was assessed by Alamar Blue assay (E). Experiments were performed in triplicate and results were expressed as \% of controls. Symbols * and \# indicate significant difference from controls $(p<0.05)$. 
(A)

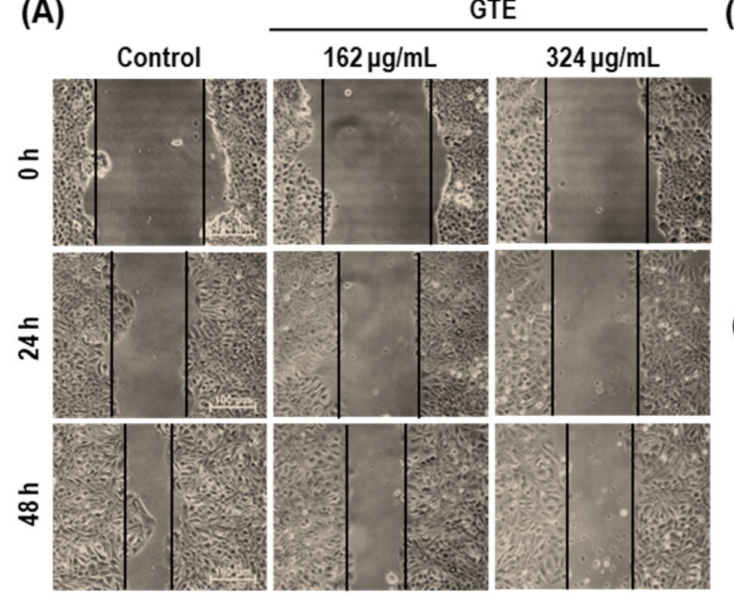

(B)

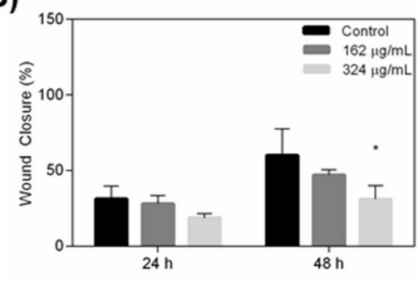

(C)

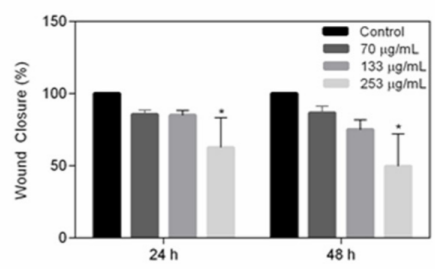

(D)

GTE

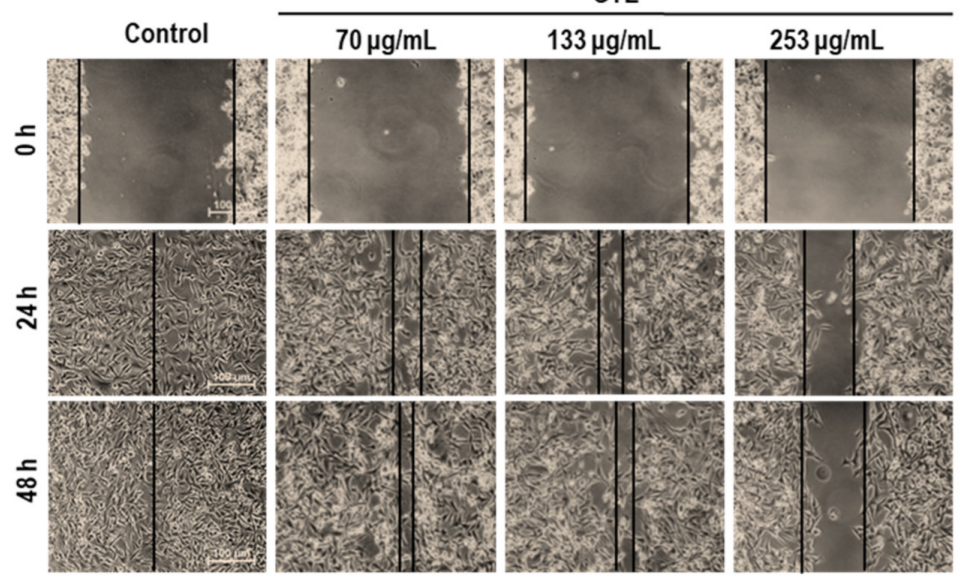

Figure 3. GTE reduces MCF-7 and MDA-MB-231 cells migration. Cell migration was assessed by hound healing assay during 24 and $48 \mathrm{~h}$. Cells were cultured to $60 \%$ confluence, scratched with a sterile plastic tip and treated with GTE. Mitomycin C $(0.5 \mu \mathrm{g} / \mathrm{mL})$ was added as a cell proliferation inhibitor. The images of MCF-7 cells (A) and MDA-MB-231 cells (D) were acquired and the wound width was measured using the ImageJ software $(n=3)(\mathbf{B}, \mathbf{C})$. We considered statistically different $\left.{ }^{*}\right)$ those where $p<0.05$.

\section{4. $p 53$ and $p 21$ Were Modulated by Green Tea Extract}

A variety of phenolic compounds target p53-family proteins, which represents a promising strategy for tumor control. Therefore, we investigated p53 levels on GTE-treated tumor cells (Figures 4 and 5). GTE exposition increased the expression of wild-type p53 protein on MCF-7 cells (Figure 4A-C). The opposite effect was observed in p53-mutant MDA-MB-231 cell (Figure 5A-C). From the results obtained, we aimed to evaluate the influence of p53 on cell viability, and a new assay using pifithrin- $\alpha$, a specific p53 inhibitor that blocks the transcription of p53 responsive genes, was conducted. Our results showed that inhibition of p53 led to increased survival of both tumor lines treated with GTE, especially MCF-7, where an almost $50 \%$ increase in the viability could be observed on cells treated with $250 \mu \mathrm{g} / \mathrm{mL}$ of GTE (Figures $4 \mathrm{~F}$ and $5 \mathrm{~F}$ ). The cyclin-dependent kinase (CDK) inhibitor p21 is recognized as the major mediator of p53-dependent cell cycle arrest. Since p53 expression levels were modulated by GTE on MCF-7 and MDA-MB-231 breast cancer cells, we also evaluated GTE-effects on p21 expression. Our results demonstrated that $24 \mathrm{~h}$ GTE exposure at $324 \mu \mathrm{g} / \mathrm{mL}$ of MCF-7 cells promoted a significant activation of p21, whereas no effect was observed on MDA-MB-231 cells (Figures 4D,E and 5D,E). 
(A)

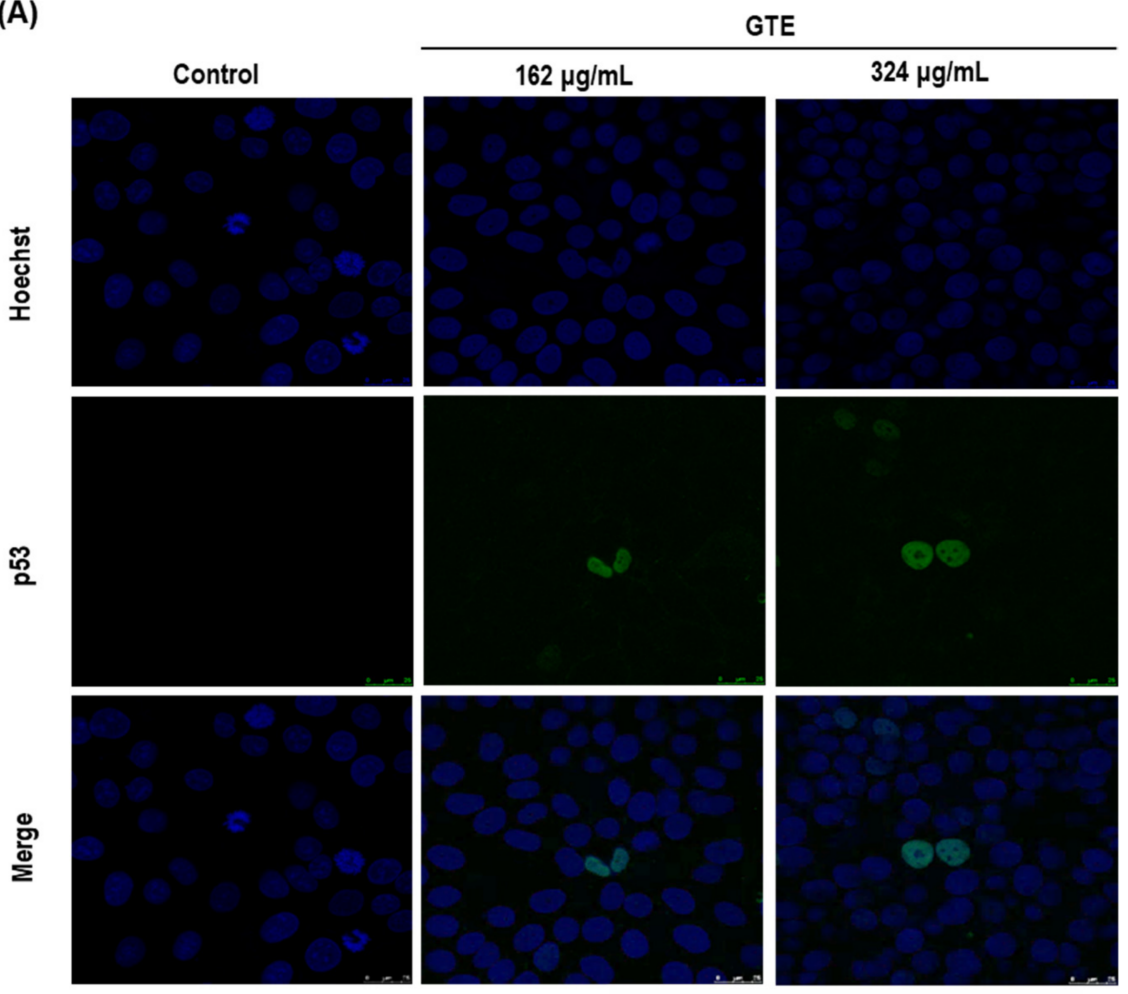

(B)

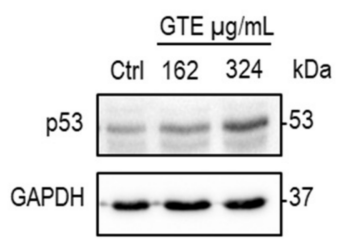

(C)

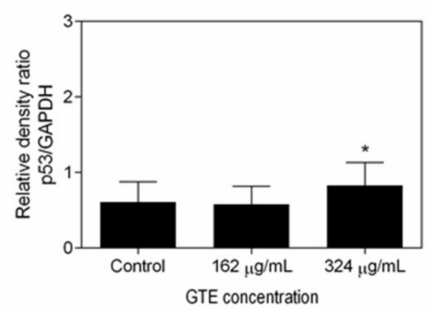

(D)

(E)
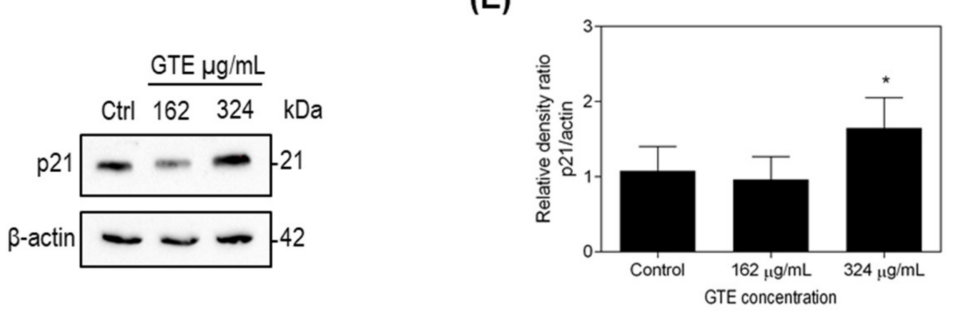

(F)

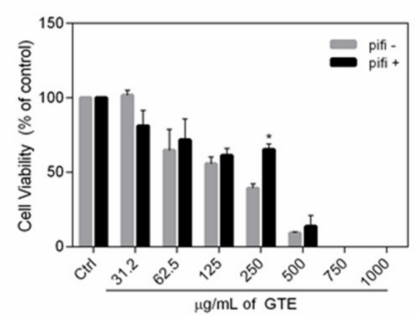

Figure 4. GTE stimulates p53 and p21 in MCF-7 cells. Immunocytochemistry assay demonstrated p53 distribution on cells (A). p53 and p21 protein levels were accessed by Western blotting and GAPDH or $\beta$-actin were used as controls. The densitometric quantification of bands shows p53 $(n=5)(\mathbf{B}, \mathbf{C})$ and p21 $(n=3)(\mathbf{D}, \mathbf{E})$ levels in MDA-MB-231. Cell viability of GTE-treated cells was assessed by Trypan Blue in the presence of a p53 inhibitor (pifithrin- $\alpha$ ) and results were expressed as $\%$ of controls $(n=3)(\mathbf{F})$. Symbol ${ }^{*}$ indicates significant difference from controls $(p<0.05)$. 
(A)
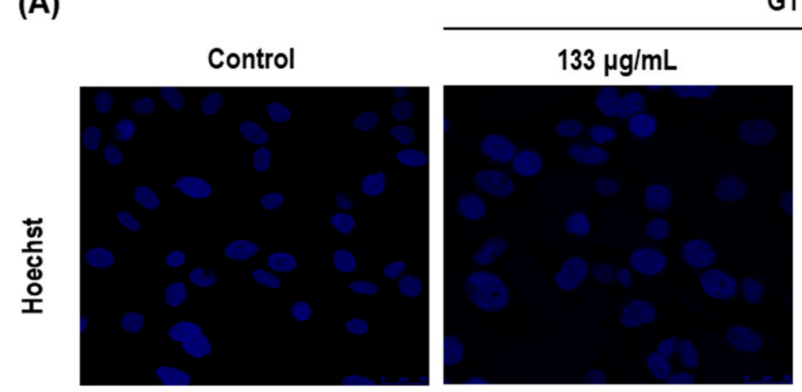

GTE
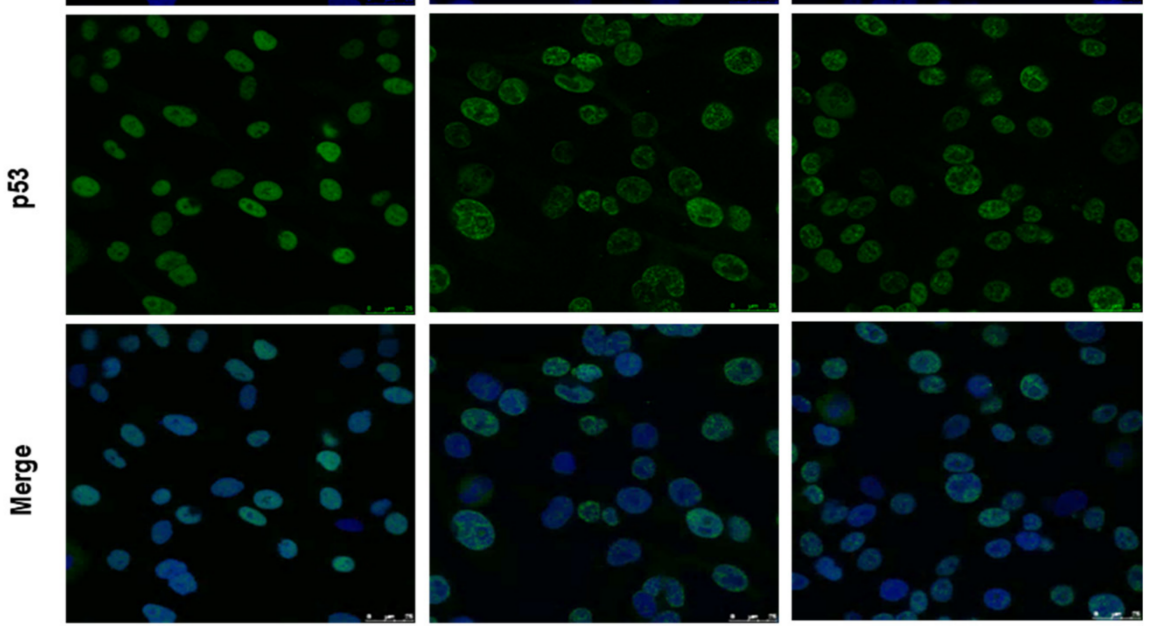

(B)

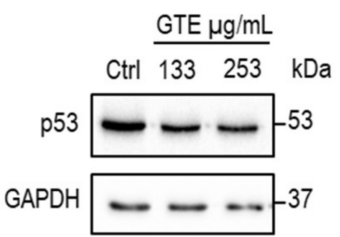

(C)

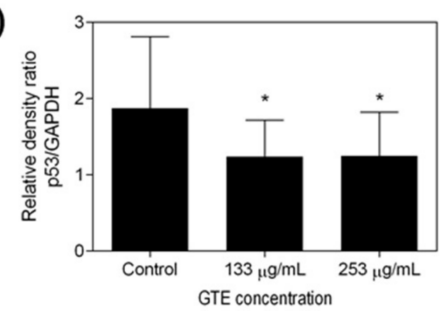

(D)

(E)
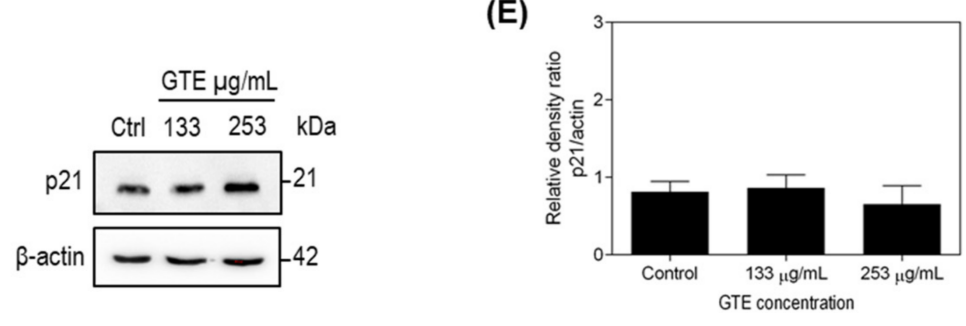

(F)

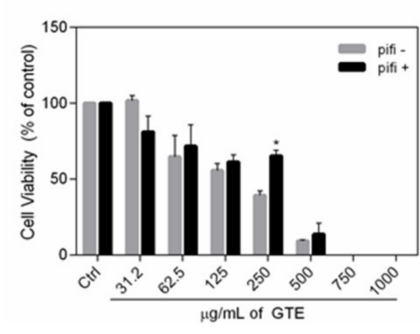

Figure 5. GTE stimulates p53 but not p21 in MDA-MB-231 cells. Immunocytochemistry assay demonstrated p53 distribution on cells (A). p53 and p21 protein levels were accessed by Western blotting and GAPDH or $\beta$-actin were used as controls. The densitometric quantification of bands shows p53 $(n=5)(\mathbf{B}, \mathbf{C})$ and p21 $(n=3)(\mathbf{D}, \mathbf{E})$ levels in MDA-MB-231. Cell viability of GTE-treated cells was assessed by Trypan Blue in the presence of a p53 inhibitor (pifithrin- $\alpha$ ) and results were expressed as $\%$ of controls $(n=3)(\mathbf{F})$. Symbol * indicates significant difference from controls $(p<0.05)$. 


\section{Discussion}

Natural products are a source of anticancer bioactive compounds and attracted great interest in cancer research. GT polyphenols have demonstrated chemopreventive and chemotherapeutic properties, by inhibiting mutagenesis as well as tumor promotion and progression $[16,33]$. Despite the advances in research, carcinogenesis is a complex and multistage process and its underlying mechanisms are not yet well understood $[34,35]$.

In the present study, we showed that the GTE obtained from the food matrix, rich in EGCG and EGC, was able to modulate p53 levels and reduce viability and migration on breast cancer cells. GT polyphenols are colorless, astringent, water-soluble compounds sensitive to different forms of degradation [36]. For this reason, the application of GT as an antioxidant source precedes the definition of the optimal conditions for the extraction of flavonoids. Thus, we first considered the effects of infusion time and temperature on the total polyphenols content of GT. Our findings demonstrate that the conditions adopted did not influence the total polyphenols content or antioxidant capacity of GTE.

However, it is correct to assume that high temperatures exert a greater influence on the degradation of the polyphenols since condition above $80^{\circ} \mathrm{C}$ facilitates epimerization of catechins [37]. Aiming to mimic the process generally used in tea preparation by consumers, we choose for the binomial $80^{\circ} \mathrm{C} / 5 \mathrm{~min}$. to the next analysis. We also determined the content of catechins of GTE by HPLC and the four mains catechins described in GT leaves with the predominance of EGCG and ECG were identified, supporting the potential for the application in cell culture. Studies have shown that Brazilian tea has a greater amount of phenolic compounds when compared to teas from other countries, due to characteristics of our climate, because the content of EGCG seems to be benefited by summer compared to spring [38].

Plant sources are widely used for naturally derived anticancer agents [39-41]. GT is a complex food matrix and tea catechins pharmacokinetics was previously studied. EGC, EC, and EGCG were detected on human plasma 1-2 $\mathrm{h}$ after drinking the equivalent of two cups of tea. Although the greatest fraction of EGCG ingested does not reach the bloodstream and EGC and EC seem to be more bioavailable, EGCG has a longer plasma half-life [42]. In rats, the isotope (-)-[4-3H] epigallocatechin gallate was detected in different organs and tissues, such as the liver, brain, eye, thymus, lung, heart, spleen, liver, pancreas, kidney, testis, prostate, and adrenal gland [30]. These findings demonstrate the absorption and delivery capacity of at least part of intact catechins to body tissues, thus suggesting a potential for biological application. Although intact catechins reach the bloodstream and were detected in a number of tissues, the fermentation by colonic microbiota is a crucial step in the metabolism of phenolic compounds that could not be analyzed in this study, which denotes a limitation.

The antitumor potential of catechins on different experimental models has previously been described in the literature. However, it is important to understand its effects as presented in the food matrix rather than the use of isolated catechins. It is known that exposure to these compounds as naturally occurring in food is an important factor for its antioxidant power and biological bioavailability, strengthening the importance of studies that fill this gap [14]. For this reason, GTE was applied in two breast tumor lines with different phenotypic characteristics. MDA-MB-231 cells showed a highly invasive and metastatic phenotype and expressed mutant $\mathrm{p} 53$ protein. MCF-7, less invasive cells, formed tightly cohesive structures displaying robust cell-cell adhesions and expressed wild-type p53 [43]. GTE demonstrates the potential to reduce the viability of both tumor cell lines, downregulating mitochondrial enzyme activity and promoting plasma membrane damage without, however, causing a cytotoxic effect on non-tumor cells (MCF-10A). In addition, the selective index (SI) of GTE to tumor cells demonstrates little potential for adverse effects, since an SI value less than two indicates general toxicity of the compound [31]. It is important to note that GTE doses above $500 \mu \mathrm{g} / \mathrm{mL}$ were toxic to all cells studied, reducing the population by more than $70 \%$. 
Cell invasion and migration play a key role in cancer progression and constitute a challenge for tumor treatment. In this study, we demonstrated that GTE reduces cell migration in both tumor cells, with a more pronounced effect on MDA-MB-231, an interesting finding taking the highly aggressive characteristics of this cell line. A possible explanation for how GT promotes this phenomenon operates on the capacity that phenolic and non-phenolic fractions of GT have to regulate several genes responsible for cell morphology, movement, and cytoskeletal formation. Seo et al. (2016) have demonstrated that $25 \mu \mathrm{g} / \mathrm{mL}$ of the GTE affected the molecular function and morphology of U2OS-GFP- $\alpha$-tubulin cells, and the authors postulated that the mechanism of inhibition of cell migration is probably related to the rupture of the microtubules of the cytoskeleton [44]. Another hypothesis suggests that EGCG induces the expression of TIMP-3, a gene that negatively regulates matrix metalloproteinases, in both MDA-MB-231 and MCF-7 cell lines, thus culminating in the inactivation of metalloproteinases and containing tumor invasion [45]. GT catechins and polyphenols reduced five-fold the expression of MMP-9 in MDA-MB-231 cells [46].

To examine the possible molecular mechanisms by which GTE reduces cell viability, we investigated the involvement of the p53 tumor suppressor protein, a well-established target of polyphenols [47]. GTE increased wild-type p53 expression in MCF-7 cells and inhibition of p53 transcription genes by pifithrin- $\alpha$ seems to increase cell survival. This finding may provide clues as to how GTE reduces the tumor population, since increased p53 expression may lead to the induction of cell death. EGCG $(20$ and $40 \mu \mathrm{mol} / \mathrm{L})$ led to the increase in Bax/Bcl-2 ration on PC-12 cells, which is the determining factor for apoptosis [48]. EGCG also reduced esophageal cancer cells ECa109 viability (concentrations from 0, 25, 50, and 100 to $200 \mathrm{mg} / \mathrm{L}$ ) while significantly increasing the rate of apoptosis [49].

Alterations in the protein expression of cell cycle and apoptosis-related genes after exposition to GTE from the food matrix provide further clues about its mechanisms of action. In this study, we observed upregulation of wild-type p53 and a significant increase in p21 levels in MCF-7 cells. Previous studies indicated that EGCG treatment induced apoptosis in pancreatic cells due to the generation of ROS and caspase-3 and -9 activations, leading to cell-cycle arrest at G1 phase via controlling expressions of cyclin D1, cdk4, and p21CIP1 [18]. Employing nanotechnology, the effects of EGCG nanoparticles on expressions of several key regulatory proteins in PI3K-Akt pathway in MCF-7 cells was previously investigated and the treatment resulted in a significant increase in the protein expression of p21 and Bax [50]. Acting as a transcription factor, p53 activates p21 gene, which encodes p21 protein [51,52]. Thus, under the experimental conditions presented, the ability of p53 to induce its major molecular target appears functional in GTE-treated MCF-7. These data can explain, at least in part, the mechanisms involved on GTE effects on breast cancer MCF-7 cells.

p53 mutations, described in over 50\% of all human cancers, lead not only to p53 loss-offunction, but also to negative-dominant effects (neutralization of the non-mutated p53) and gain-of-function effects, assuring a more aggressive phenotype, i.e., increasing metastatic capacity, genomic instability, and resistance to chemotherapy [53,54]. GTE decreased the mutant p53 p.R280K expression in MDA-MB-231 cells and immunocytochemistry data suggests a redistribution of mutant-p53 on the cellular nucleus. As expected for a mutant p53 tumor cell line, p21 levels did not change in MDA-MB-231 cells [52].

\section{Conclusions}

Our findings indicate that GTE obtained from the food matrix selectively targeted breast cancer cells, thus reducing cell viability and migration in MDA-MB-231 and MCF-7, which suggests a high potential for application in carcinogenesis. We also observed an increase in p53 and p21 proteins expression levels on MCF-7 cells, suggesting that this phenomenon may, at least in part, be mediated by p53 protein. The opposite effect was observed in MDA-MB-231 cells, which is interesting data, considering that p53 mutations were associated with gain of oncogenic function effects. 
The main limitation of the present study is that we did not assess the exact mechanisms involved in the absorption and biotransformation of phytochemicals present in GTE by breast cancer cells. We believe that the mixture of bioactive compounds with a wide range of biological activities could have additive or synergistic effects against carcinogenesis.

This work provides new insights into the role of green tea as a whole food in p53mediated cytotoxicity and inhibition of tumor cell migration. Future studies are planned to investigate the role of p53 in GTE-induced effects in vivo and 3D cancer cell cultures, in comparison to isolated catechins.

Author Contributions: Conceptualization, R.A.S. and E.F.; methodology, R.A.S. and M.M.; validation, R.A.S. and D.C.F.d.C.; formal analysis, R.A.S. and M.M.; investigation, R.A.S., M.M. and E.D.S.A.; resources, D.C.F.d.C., J.B.D. and J.L.S.; data curation, R.A.S. and E.D.S.A.; writing—original draft preparation, R.A.S.; writing-review and editing, J.B.D., M.M., E.F., D.C.F.d.C. and E.D.S.A.; supervision, D.C.F.d.C.; project administration, D.C.F.d.C.; funding acquisition, J.L.S., J.B.D. and D.C.F.d.C. All authors have read and agreed to the published version of the manuscript.

Funding: This study was funded by the Coordenação de Aperfeiçoamento de Pessoal de Nível Superior-Brazil (CAPES)—Finance Code 001, Conselho Nacional de Desenvolvimento Científico e Tecnológico (CNPq), Fundação Carlos Chagas Filho de Amparo à Pesquisa do Estado do Rio de Janeiro (FAPERJ E-26/203-259/2017 and FAPERJ E-26/010.001323/2019) and Fundação do Câncer.

Institutional Review Board Statement: Not applicable.

Informed Consent Statement: Not applicable.

Acknowledgments: We thank Joel Pimentel de Abreu for their fruitful collaboration with GTE production.

Conflicts of Interest: The authors declare no conflict of interest.

\section{References}

1. Seow, W.J.; Yanwen, D.L.; Pan, W.; Gunther, S.H.; Sim, X.; Torta, F.; Herr, D.R.; Kovalik, J.; Jianhong, C.; Khoo, C.M.; et al. Coffee, Black Tea, and Green Tea Consumption in Relation to Plasma Metabolites in an Asian Population. Mol. Nutr. Food Res. 2020, 64, 2000527. [CrossRef]

2. Fang, Z.T.; Song, C.J.; Xu, H.R.; Ye, J.H. Dynamic changes in flavonol glycosides during production of green, yellow, white, oolong and black teas from Camellia sinensis L. (cv. Fudingdabaicha). Int. J. Food Sci. Technol. 2019, 54, 490-498. [CrossRef]

3. Chang, K. World tea production and trade Current and future development. In Food and Agriculture Organization of the United Nations; FAO: Rome, Italy, 2015.

4. Graham, H.N. Green Tea Composition, Consumption and Polyphenol Chemistry. Prev. Med. (Baltim.) 1992, 21, 334-350. [CrossRef]

5. Cheng, W.H. Green Tea: An Ancient Antioxidant Drink for Optimal Health? J. Nutr. 2019, 149, 1877-1879. [CrossRef]

6. Koch, W. Dietary polyphenols-important non-nutrients in the prevention of chronic noncommunicable diseases. A systematic review. Nutrients 2019, 11, 1039. [CrossRef] [PubMed]

7. Bernatoniene, J.; Kopustinskiene, D.M. The Role of Catechins in Cellular Responses to Oxidative Stress. Molecules 2018, 23, 965. [CrossRef]

8. Gianfredi, V.; Nucci, D.; Abalsamo, A.; Acito, M.; Villarini, M.; Moretti, M.; Realdon, S. Green tea consumption and risk of breast cancer and recurrence-A systematic review and meta-analysis of observational studies. Nutrients 2018, 10, 1886. [CrossRef]

9. Yu, S.; Zhu, L.; Wang, K.; Yan, Y.; He, J.; Ren, Y. Green tea consumption and risk of breast cancer: A systematic review and updated meta-analysis of case-control studies. Medicine (Baltimore) 2019, 98, 27. [CrossRef]

10. Kim, T.L.; Jeong, G.H.; Yang, J.W.; Lee, K.H.; Kronbichler, A.; Van Der Vliet, H.J.; Grosso, G.; Galvano, F.; Aune, D.; Kim, J.Y.; et al. Tea Consumption and Risk of Cancer: An Umbrella Review and Meta-Analysis of Observational Studies. Adv. Nutr. 2020, 11, 1437-1452. [CrossRef]

11. Filippini, T.; Malavolti, M.; Borrelli, F.; Izzo, A.A.; Fairweather-Tait, S.J.; Horneber, M.; Vinceti, M. Green tea (Camellia sinensis) for the prevention of cancer. Cochrane Database Syst. Rev. 2020, 3. [CrossRef]

12. Sung, H.; Ferlay, J.; Siegel, R.L.; Laversanne, M.; Soerjomataram, I.; Jemal, A.; Bray, F. Global Cancer Statistics 2020: GLOBOCAN Estimates of Incidence and Mortality Worldwide for 36 Cancers in 185 Countries. CA Cancer J. Clin. 2021, 71, 209-249. [CrossRef]

13. Wang, L.; Zhang, S.; Wang, X. The Metabolic Mechanisms of Breast Cancer Metastasis. Front. Oncol. 2021, 10, 2942. [CrossRef] [PubMed]

14. Kapinova, A.; Stefanicka, P.; Kubatka, P.; Zubor, P.; Uramova, S.; Kello, M.; Mojzis, J.; Blahutova, D.; Qaradakhi, T.; Zulli, A.; et al. Are plant-based functional foods better choice against cancer than single phytochemicals? A critical review of current breast cancer research. Biomed. Pharmacother. 2017, 96, 1465-1477. [CrossRef] 
15. Kotecha, R.; Takami, A.; Espinoza, J.L. Dietary phytochemicals and cancer chemoprevention: A review of the clinical evidence. Oncotarget 2016, 7, 52517-52529. [CrossRef] [PubMed]

16. Mocanu, M.M.; Nagy, P.; Szöllosi, J.; Vanden Eynde, J.J.; Mayence, A. Chemoprevention of breast cancer by dietary polyphenols. Molecules 2015, 20, 22578-22620. [CrossRef]

17. Gan, R.-Y.; Li, H.-B.; Sui, Z.-Q.; Corke, H. Absorption, metabolism, anti-cancer effect and molecular targets of epigallocatechin gallate (EGCG): An updated review. Crit. Rev. Food Sci. Nutr. 2018, 58, 924-941. [CrossRef]

18. Shirakami, Y.; Shimizu, M. Possible mechanisms of green tea and its constituents against cancer. Molecules 2018, $23,2284$. [CrossRef]

19. Musial, C.; Alicja Kuban-Jankowska, M.G.-P. Beneficial properties of green tea. Int. J. Mol. Sci. 2020, 21, 1744. [CrossRef] [PubMed]

20. Vogelstein, B.; Lane, D.L.; Levine, A.J. Surfing the p53 network. Nature 2000, 408, 307-310. [CrossRef]

21. da Costa, D.C.F.; Fialho, E.; Silva, J. Cancer Chemoprevention by Resveratrol: The p53 Tumor Suppressor Protein as a Promising Molecular Target. Molecules 2017, 22, 1014. [CrossRef]

22. Khan, H.; Reale, M.; Ullah, H.; Sureda, A.; Tejada, S.; Wang, Y.; Zhang, Z.J.; Xiao, J. Anti-cancer effects of polyphenols via targeting p53 signaling pathway: Updates and future directions. Biotechnol. Adv. 2020, 38, 107385. [CrossRef] [PubMed]

23. Koss-Mikołajczyk, I.; Kusznierewicz, B.; Bartoszek, A. The relationship between phytochemical composition and biological activities of differently pigmented varieties of berry fruits; comparison between embedded in food matrix and isolated anthocyanins. Foods 2019, 8, 646. [CrossRef] [PubMed]

24. Hu, J.; Webster, D.; Cao, J.; Shao, A. The safety of green tea and green tea extracts consumption in adults-Results of a systematic review. Regul. Toxicol. Pharmacol. 2018, 95, 412-433. [CrossRef]

25. Oketch-Rabah, H.A.; Roe, A.L.; Rider, C.V.; Bonkovsky, H.L.; Giancaspro, G.I.; Navarro, V.; Paine, M.F.; Betz, J.M.; Marles, R.J.; Casper, S.; et al. United States Pharmacopeia (USP) comprehensive review of the hepatotoxicity of green tea extracts. Toxicol. Rep. 2020, 7, 386-402. [CrossRef]

26. Cheng, Z.; Zhang, Z.; Han, Y.; Wang, J.; Wang, Y.; Chen, X.; Shao, Y.; Cheng, Y.; Zhou, W.; Lu, X.; et al. A review on anti-cancer effect of green tea catechins. J. Funct. Foods 2020, 74, 104172. [CrossRef]

27. Singleton, V.L.; Orthofer, R.; Lamuela-Raventós, R.M. Analysis of Total Phenols and Other Oxidation Substrates and Antioxidants by Means of Folin-Ciocalteu Reagent. Methods Enzymol. 1999, 299, 152-178.

28. Benzie, I.F.F.; Szeto, Y.T. Total antioxidant capacity of teas by the ferric reducing/ antioxidant power assay. J. Agric. Food Chem. 1999, 47, 633-636. [CrossRef]

29. Benzie, I.; Strain, J. The ferric reducing ability of plasma (FRAP) as a measure of "antioxidant power": The FRAP assay. Anal. Biochem. 1996, 239, 70-76. [CrossRef]

30. Kohri, T.; Matsumoto, N.; Yamakawa, M.; Suzuki, M.; Nanjo, F.; Hara, Y.; Oku, N. Metabolic Fate of (-)-[4-3H]Epigallocatechin Gallate in Rats after Oral Administration. J. Agric. Food Chem. 2001, 49, 4102-4112. [CrossRef]

31. Koch, A.; Tamez, P.; Pezzuto, J.; Soejarto, D. Evaluation of plants used for antimalarial treatment by the Maasai of Kenya. J. Ethnopharmacol. 2005, 101, 95-99. [CrossRef]

32. Ferretti, G.D.D.S.; da Costa, D.C.F.; Silva, J.L.; Pereira Rangel, L. Methods to screen compounds against mutant p53 misfolding and aggregation for cancer therapeutics. In Protein Misfolding Diseases; Humana Press: New York, NY, USA, 2019 ; pp. $265-277$. ISBN 9781493988204.

33. Tang, G.Y.; Meng, X.; Gan, R.Y.; Zhao, C.N.; Liu, Q.; Feng, Y.B.; Li, S.; Wei, X.L.; Atanasov, A.G.; Corke, H.; et al. Health functions and related molecular mechanisms of tea components: An update review. Int. J. Mol. Sci. 2019, 20, 6196. [CrossRef]

34. Hanahan, D.; Weinberg, R.A. Hallmarks of cancer: The next generation. Cell 2011, 144, 646-674. [CrossRef] [PubMed]

35. Hanahan, D.; Weinberg, R.A. Biology Hallmarks of Cancer. Holland-Frei Cancer Med. 2016, 1-10. [CrossRef]

36. Donlao, N.; Ogawa, Y. The influence of processing conditions on catechin, caffeine and chlorophyll contents of green tea (Camelia sinensis) leaves and infusions. LWT 2019, 116, 108567. [CrossRef]

37. Wang, H.; Helliwell, K. Epimerisation of catechins in green tea infusions. Food Chem. 2000, 70, 337-344. [CrossRef]

38. Saito, S.T.; Fröehlich, P.E.; Gosmann, G.; Bergold, A.M. Full Validation of a Simple Method for Determination of Catechins and Caffeine in Brazilian Green Tea (Camellia sinensis var. assamica) Using HPLC. Chromatographia 2007, 65, 607-610. [CrossRef]

39. Phan, N.L.-C.; Pham, K.D.; Nguyen, M.T.-T.; Phan, N.K.; Truong, K.D.; Van Pham, P. Anti-tumor activity of plant extracts against human breast cancer cells are different in monolayer and three-dimensional cell culture screening models: A comparison on 34 extracts. Biomed. Res. Ther. 2020, 7, 3667-3677. [CrossRef]

40. Abdelhamed, S.; Yokoyama, S.; Hafiyani, L.; Kalauni, S.K.; Hayakawa, Y.; Awale, S.; Saiki, I. Identification of plant extracts sensitizing breast cancer cells to TRAIL. Oncol. Rep. 2013, 29, 1991-1998. [CrossRef]

41. Cross, S.E.; Jin, Y.; Tondre, J.; Leporatti, S.; Vergara, D.; Zacheo, A.; Vergara, D.; Martignago, R.; Leporatti, S.; Cross, S.E.; et al Green tea extract selectively targets nanomechanics of live metastatic cancer cells. Nanotechnology 2011, 22, 215101. [CrossRef]

42. Lee, M.; Maliakal, P.; Chen, L.; Meng, X.; Bondoc, F. Pharmacokinetics of Tea Catechins after Ingestion of Green Tea and (-)Epigallocatechin-3-gallate by Humans-Cancer Epidemiology, Biomarkers \& Prevention. Cancer Epidemiol. 2002, 11, $1025-1032$.

43. Holliday, D.L.; Speirs, V. Choosing the right cell line for breast cancer research. Breast Cancer Res. 2011, 13, 1-7. [CrossRef]

44. Seo, E.J.; Wu, C.F.; Ali, Z.; Wang, Y.H.; Khan, S.I.; Walker, L.A.; Khan, I.A.; Efferth, T. Both phenolic and non-phenolic green tea fractions inhibit migration of cancer cells. Front. Pharmacol. 2016, 7, 398. [CrossRef] [PubMed] 
45. Deb, G.; Thakur, V.S.; Limaye, A.M.; Gupta, S. Epigenetic induction of tissue inhibitor of matrix metalloproteinase-3 by green tea polyphenols in breast cancer cells. Mol. Carcinog. 2015, 54, 485-499. [CrossRef] [PubMed]

46. Thangapazham, R.L.; Passi, N.; Maheshwari, R.K. Green tea polyphenol and epigallocatechin gallate induce apoptosis and inhibit invasion in human breast cancer cells. Cancer Biol. Ther. 2007, 6, 1938-1943. [CrossRef]

47. Etienne-Selloum, N.; Dandache, I.; Sharif, T.; Auger, C.; Schini-Kerth, V.B. Polyphenolic Compounds Targeting p53-Family Tumor Suppressors: Current Progress and Challenges. Futur. Asp. Tumor Suppressor Gene 2013, 129-167. [CrossRef]

48. Hu, Q.; Chang, X.; Yan, R.; Rong, C.; Yang, C.; Cheng, S.; Gu, X.; Yao, H.; Hou, X.; Mo, Y.; et al. (-)-Epigallocatechin-3-gallate induces cancer cell apoptosis via acetylation of amyloid precursor protein. Med. Oncol. 2015, 32, 390. [CrossRef] [PubMed]

49. Meng, J.; Tong, Q.; Liu, X.; Yu, Z.; Zhang, J.; Gao, B. Epigallocatechin-3-gallate inhibits growth and induces apoptosis in esophageal cancer cells through the demethylation and reactivation of the p16 gene. Oncol. Lett. 2017, 14, 1152-1156. [CrossRef]

50. Zeng, L.; Yan, J.; Luo, L.; Ma, M.; Zhu, H. Preparation and characterization of (-)-Epigallocatechin-3-gallate (EGCG)-loaded nanoparticles and their inhibitory effects on Human breast cancer MCF-7 cells. Sci. Rep. 2017, 7, 1-15. [CrossRef]

51. Wade Harper, J.; Adami, G.R.; Wei, N.; Keyomarsi, K.; Elledge, S.J. The p21 Cdk-interacting protein Cip1 is a potent inhibitor of G1 cyclin-dependent kinases. Cell 1993, 75, 805-816. [CrossRef]

52. El-deiry, W.S.; Tokino, T.; Velculescu, V.E.; Levy, D.B.; Parsons, R.; Trent, J.M.; Lin, D.; Mercer, W.E.; Kinzler, K.W.; Vogelstein, B. WAF1, a Potential Mediator of p53 Tumor Suppression. Cell Press 1993, 75, 817-825. [CrossRef]

53. Silva, J.L.; Gallo, C.V.D.M.; Costa, D.C.F.; Rangel, L.P. Prion-like aggregation of mutant p53 in cancer. Trends Biochem. Sci. 2014, 39, 260-267. [CrossRef] [PubMed]

54. Muller, P.A.J.; Vousden, K.H. p53 Mutations in Cancer. Nat. Cell Biol. 2013, 15, 2-8. [CrossRef] [PubMed] 